\title{
\#USGS
}

science for a changing world

Prepared in cooperation with the Will County Stormwater Management Planning Committee

\section{Flood-Inundation Maps for the DuPage River from Plainfield to Shorewood, Illinois, 2013}

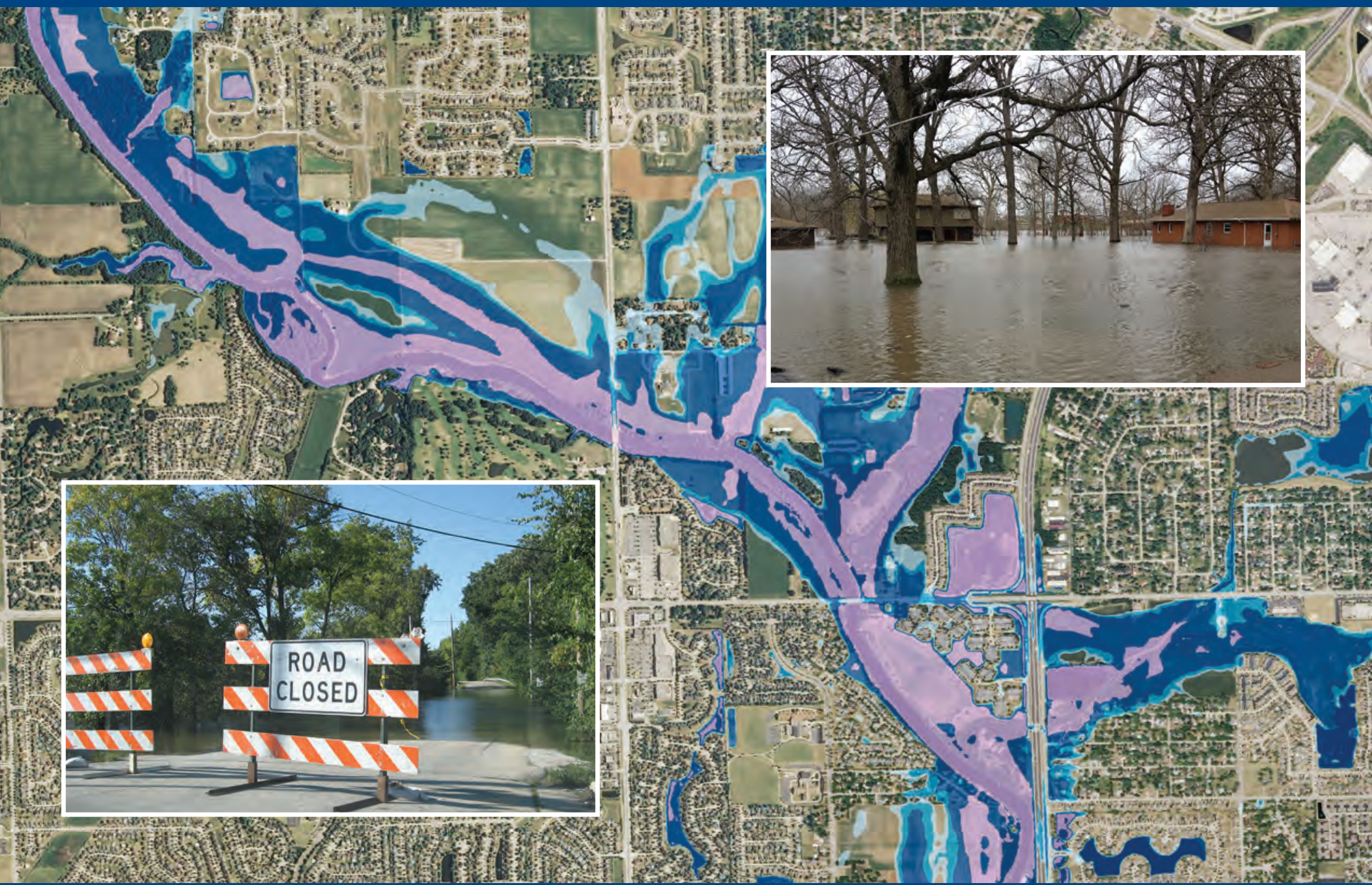

Pamphlet to accompany

Scientific Investigations Map 3275

U.S. Department of the Interior

U.S. Geological Survey 


\section{Cover images:}

Background: Inundation depths along the DuPage River at a gage height of 14 feet referenced to the U.S. Geological Survey streamgage at Shorewood, Illinois.

Upper right: Houses on River Road in Plainfield Township inundated by the DuPage River during the April 2013 flooding. (Photograph by Will County staff.)

Lower left: Sign on South Lily Cache Rd just north of West Caton Farm Road during the September 2008 flooding. (Photograph by Will County staff.) 


\section{Flood-Inundation Maps for the DuPage River from Plainfield to Shorewood, Illinois, 2013}

By Elizabeth A. Murphy and Jennifer B. Sharpe

Prepared in cooperation with the Will County Stormwater Management

Planning Committee

Pamphlet to accompany

Scientific Investigations Map 3275 


\title{
U.S. Department of the Interior SALLY JEWELL, Secretary
}

\section{U.S. Geological Survey Suzette M. Kimball, Acting Director}

\author{
U.S. Geological Survey, Reston, Virginia: 2013
}

For more information on the USGS - the Federal source for science about the Earth, its natural and living resources, natural hazards, and the environment, visit http://www.usgs.gov or call 1-888-ASK-USGS.

For an overview of USGS information products, including maps, imagery, and publications, visit http://www.usgs.gov/pubprod

To order this and other USGS information products, visit http://store.usgs.gov

Any use of trade, firm, or product names is for descriptive purposes only and does not imply endorsement by the U.S. Government.

Although this information product, for the most part, is in the public domain, it also may contain copyrighted materials as noted in the text. Permission to reproduce copyrighted items must be secured from the copyright owner.

Suggested citation:

Murphy, E.A. and Sharpe, J.B., 2013, Flood-inundation maps for the DuPage River from Plainfield to Shorewood, Illinois, 2013: U.S. Geological Survey Scientific Investigations Map 3275, 9 sheets, 8-p. pamphlet,

http://dx.doi.org/10.3133/sim/3275. 


\section{Acknowledgments}

The authors wish to thank the many local, State, and Federal agencies that provided funding and cooperated in the operation and maintenance of the gages used for this study. Special thanks are given to Derek O'Sullivan, Thomas Carroll and other staff at the Will County Stormwater Management Planning Committee and to the Illinois State Water Survey for providing the crosssection shapefile. Additional thanks are given to Alexander Paul and Terry Ortel for their work on the design of the inundation mapping Web site. 



\section{Contents}

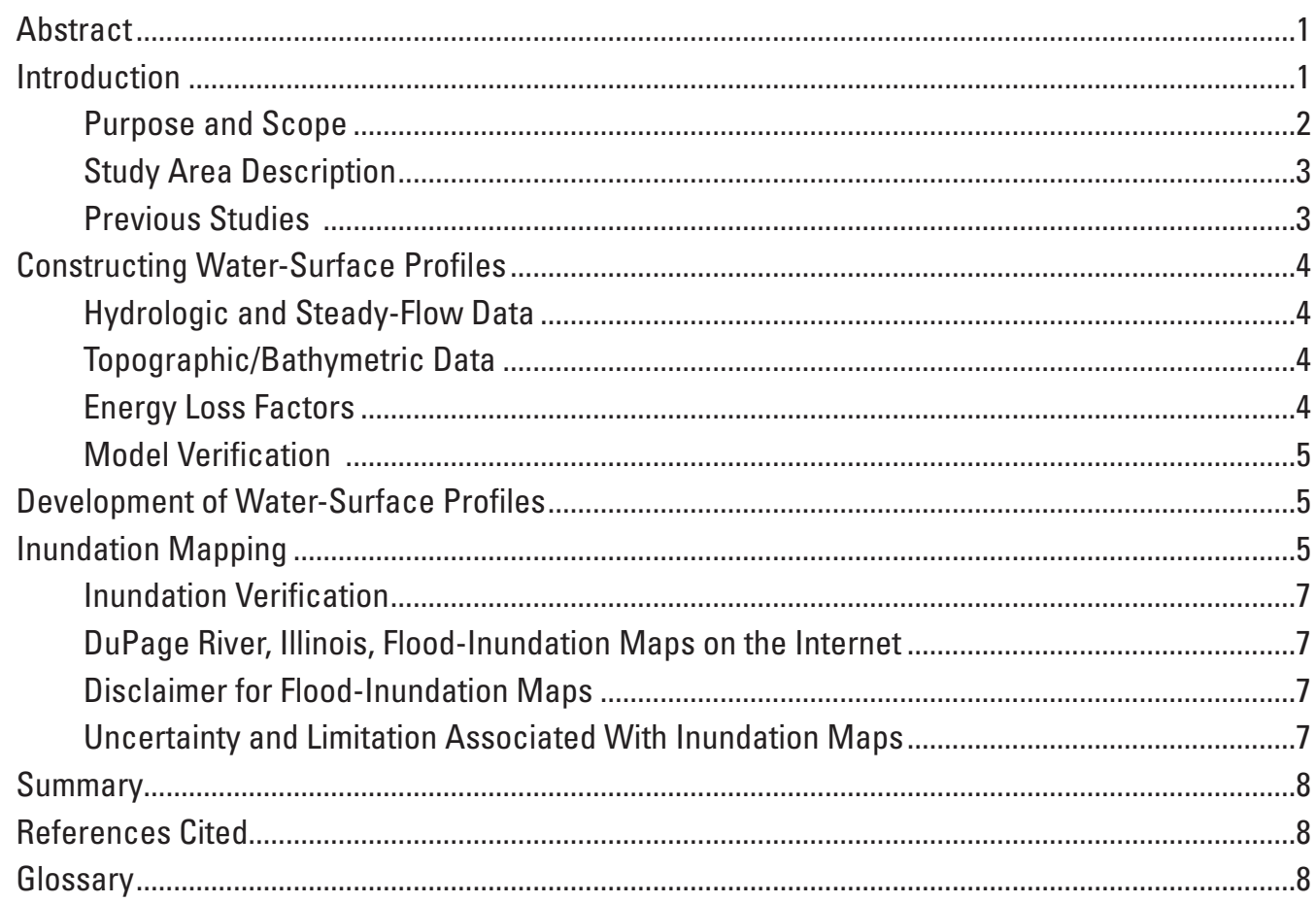

\section{Figures}

1. Map showing location of study reach for the DuPage River, Illinois, and location of U.S. Geological Survey streamgages and National Weather Service forecast point. .....2

2. A, Aerial photograph taken after the flood peak in September 2008 overlaid with simulated flood inundation corresponding to a gage height (elevation) of 10.0 (574.3) feet at U.S. Geological Survey streamgage number 05540500, DuPage River at Shorewood, Illinois, and $B$, photos of flooding along the DuPage River on September 14,2008 , at locations 1 and 2 in photo $A$. The peak gage height for this flood was measured at 9.94 feet at the Shorewood streamgage on September 15, 2008.

\section{Tables}

1. U.S. Geological Survey streamgage information for study area, DuPage River, Illinois. .3

2. 10-, 2-, 1-, and 0.2-percent annual exceedance probability peak discharge estimates and drainage areas for selected locations on the DuPage River, Illinois (modified from Federal Emergency Management Agency, 2003).

3. Gage heights (elevations) at USGS streamgage 05540500, DuPage River at Shorewood, Illinois, with corresponding discharge estimates at selected locations along the DuPage River, Illinois, for simulated water-surface profiles. 


\section{Sheets}

Sheets and additional materials are available online at http://pubs.usgs.gov/sim/3275.

1-9. Estimated flood-inundation maps for the DuPage River from Plainfield to Shorewood, Illinois, referenced to U.S. Geological Survey streamgage DuPage River at Shorewood (station no. 05540500) and corresponding to gage heights of:

1. Gage height of 6.0 feet and an elevation of 570.3 feet

2. Gage height of 7.0 feet and an elevation of 571.3 feet

3. Gage height of 8.0 feet and an elevation of 572.3 feet

4. Gage height of 9.0 feet and an elevation of 573.3 feet

5. Gage height of 10.0 feet and an elevation of 574.3 feet

6. Gage height of 11.0 feet and an elevation of 575.3 feet

7. Gage height of 12.0 feet and an elevation of 576.3 feet

8. Gage height of 13.0 feet and an elevation of 577.3 feet

9. Gage height of 14.0 feet and an elevation of 578.3 feet

\section{Conversion Factors, Abbreviations, and Datum}

Inch/Pound to SI

\begin{tabular}{|c|c|c|}
\hline Multiply & By & To obtain \\
\hline \multicolumn{3}{|c|}{ Length } \\
\hline foot $(\mathrm{ft})$ & 0.3048 & meter $(\mathrm{m})$ \\
\hline mile (mi) & 1.609 & kilometer (km) \\
\hline \multicolumn{3}{|c|}{ Area } \\
\hline square mile $\left(\mathrm{mi}^{2}\right)$ & 2.590 & square kilometer $\left(\mathrm{km}^{2}\right)$ \\
\hline \multicolumn{3}{|c|}{ Flow rate } \\
\hline cubic foot per second $\left(\mathrm{ft}^{3} / \mathrm{s}\right)$ & 0.02832 & cubic meter per second $\left(\mathrm{m}^{3} / \mathrm{s}\right)$ \\
\hline \multicolumn{3}{|c|}{ Hydraulic gradient } \\
\hline foot per mile (ft/mi) & 0.1894 & meter per kilometer $(\mathrm{m} / \mathrm{km})$ \\
\hline
\end{tabular}

Vertical coordinate information is referenced to the North American Vertical Datum of 1988 (NAVD 88).

Horizontal coordinate information is referenced to the North American Datum of 1983 (NAD 83).

Elevation, as used in this report, refers to distance above the vertical datum.

Selected technical terms defined in the glossary are indicated by bold type where they are first used. 


\title{
Flood-Inundation Maps for the DuPage River from Plainfield to Shorewood, Illinois, 2013
}

\author{
By Elizabeth A. Murphy and Jennifer B. Sharpe
}

\begin{abstract}
Digital flood-inundation maps for a 15.5 -mi reach of the DuPage River from Plainfield to Shorewood, Illinois, were created by the U.S. Geological Survey (USGS) in cooperation with the Will County Stormwater Management Planning Committee. The inundation maps, which can be accessed through the USGS Flood Inundation Mapping Science Web site at http://water.usgs.gov/osw/flood_inundation/, depict estimates of the areal extent of flooding corresponding to selected water levels (gage heights or stages) at the USGS streamgage at DuPage River at Shorewood, Illinois (sta. no. 05540500). Current conditions at the USGS streamgage may be obtained on the Internet at http://waterdata.usgs.gov/usa/nwis/ $u v ? 05540500$. In addition, the information has been provided to the National Weather Service (NWS) for incorporation into their Advanced Hydrologic Prediction Service (AHPS) flood warning system (http://water.weather.gov/ahps/). The NWS forecasts flood hydrographs at many places that are often colocated with USGS streamgages. The NWS-forecasted peak-stage information, also shown on the DuPage River at Shorewood inundation Web site, may be used in conjunction with the maps developed in this study to show predicted areas of flood inundation.

In this study, flood profiles were computed for the stream reach by means of a one-dimensional step-backwater model. The hydraulic model was then used to determine nine watersurface profiles for flood stages at 1 - $\mathrm{ft}$ intervals referenced to the streamgage datum and ranging from NWS Action stage of $6 \mathrm{ft}$ to the historic crest of $14.0 \mathrm{ft}$. The simulated water-surface profiles were then combined with a Digital Elevation Model (DEM) (derived from Light Detection And Ranging (LiDAR) data) by using a Geographic Information System (GIS) in order to delineate the area flooded at each water level.

These maps, along with information on the Internet regarding current gage height from USGS streamgages and forecasted stream stages from the NWS, provide emergency management personnel and residents with information that is critical for flood response activities such as evacuations and road closures, as well as for postflood recovery efforts.
\end{abstract}

\section{Introduction}

Will County is part of the Chicago, Illinois (Ill.), metropolitan area, with an estimated population of 681,545 in 2011 (U.S. Census Bureau, 2013). Parts of Will County have experienced severe flooding numerous times, most notably in July 1996, August 2007, and September 2008. President George W. Bush signed Major Disaster Declaration FEMA-1800-DR on October 3, 2008, for Cook, DeKalb, DuPage, Grundy, Kane, LaSalle, and Will counties following severe flooding in September 2008 (Federal Emergency Management Agency, 2008). Flood plains within Will County are urbanized and contain a mix of residential and commercial structures.

Prior to this study, Will County and municipal officials relied on several information sources to make decisions on how to best alert the public about impending flooding and to mitigate flood damages. One source is the Federal Emergency Management Agency (FEMA) Flood Insurance Study (FIS) for Will County, Illinois, and Incorporated Areas, dated March 17, 2003 (Federal Emergency Management Agency, 2003). A second source of information has been the U.S. Geological Survey (USGS) streamgages, DuPage River at Shorewood, Ill. (station no. 05540500) and DuPage River near Plainfield, Ill. (station no. 05540290), from which current or historical water levels (gage heights) can be obtained. A third source has been the National Weather Service (NWS) forecast of peak stage (gage height) at the USGS Shorewood streamgage through the Advanced Hydrologic Prediction Service (AHPS) site. Although USGS current gage height and NWS forecast stage information is particularly useful for residents in the immediate vicinity of a streamgage, it is of limited use to residents farther upstream or downstream because the water-surface elevation is not constant along the entire stream channel. Also, FEMA and State emergency management mitigation teams or property owners typically lack information related to how deep the water is at locations other than near USGS streamgage or NWS flood-forecast points. 


\section{Purpose and Scope}

The purpose of this report is to (1) describe the development of a series of estimated flood-inundation maps for a 15.5-mile reach of the DuPage River between Plainfield and Shorewood, Ill., (fig.1) and (2) provide users with a library of flood-inundation maps that correspond to water levels referenced to the water-surface elevation and gage heights at the USGS streamgage on the DuPage River at Shorewood, Ill. The reference gage heights range from $6 \mathrm{ft}$ to $14 \mathrm{ft}$, corresponding to the NWS Action Stage and the historic crest, respectively. This report is a description of the DuPage River inundation maps and other flood information available on the USGS Flood Inundation Mapping Science Web site at http://water. usgs.gov/osw/flood_inundation/.

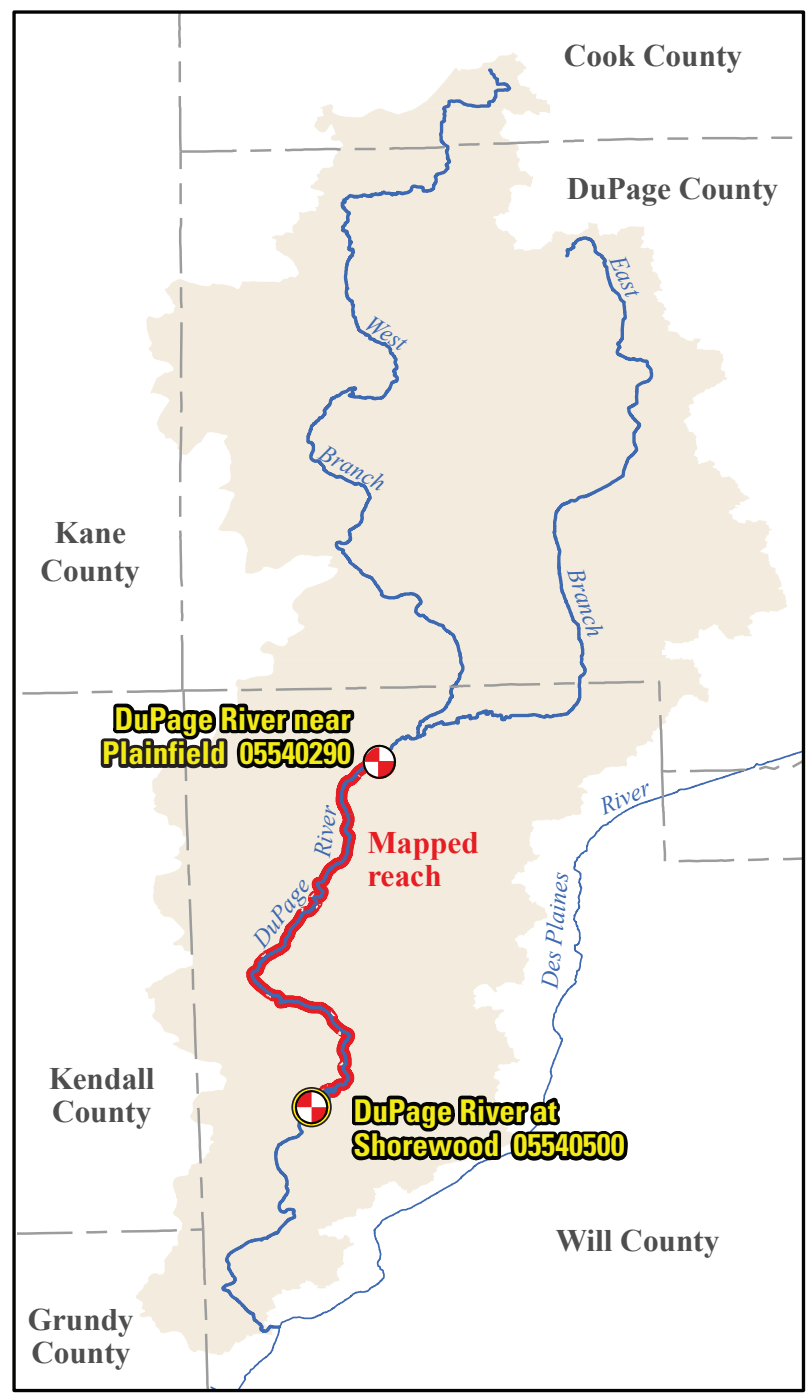

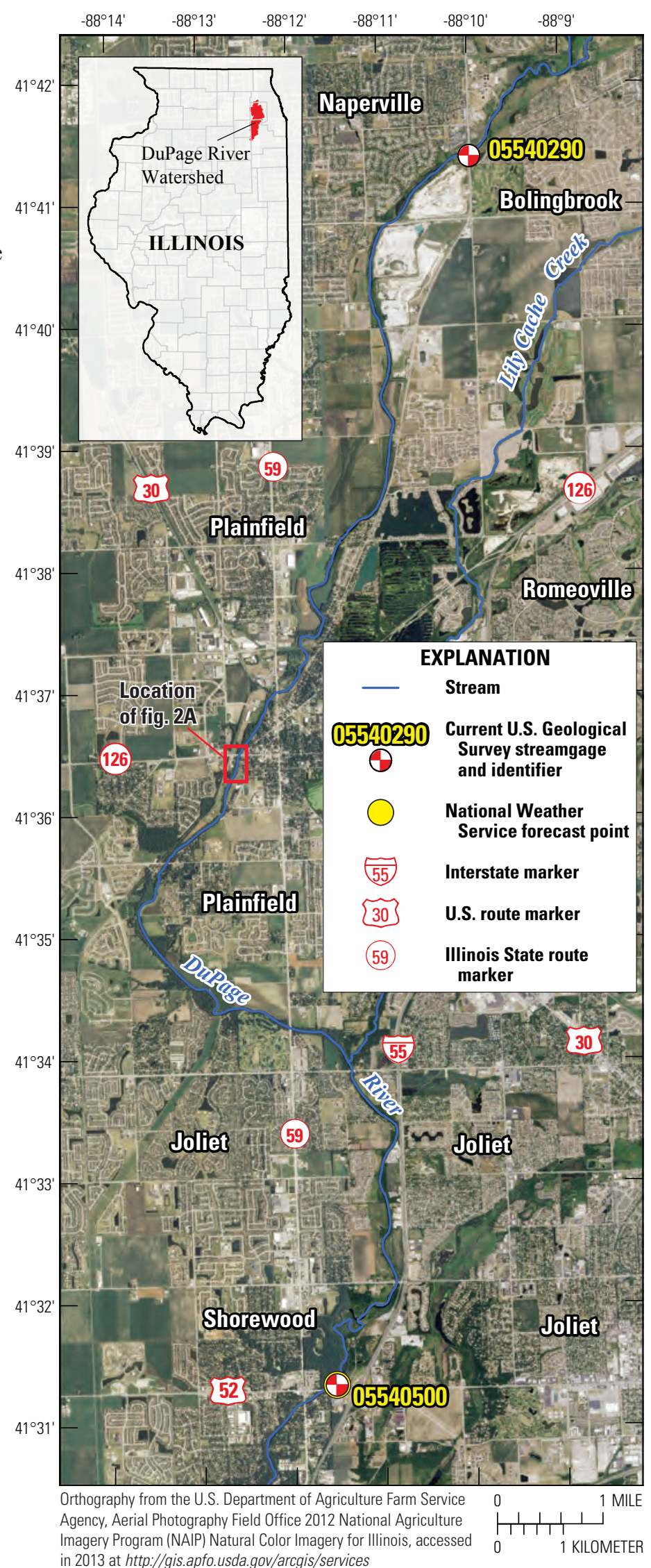

Figure 1. Location of study reach for the DuPage River, Illinois, and location of U.S. Geological Survey streamgages and National Weather Service forecast point. 


\section{Study Area Description}

The DuPage River is in northeast Illinois in the Central Lowland physiographic province (Illinois State Geological Survey, 2013). The drainage area is $324 \mathrm{mi}^{2}$ at the Shorewood streamgage and $220 \mathrm{mi}^{2}$ at the Plainfield streamgage (table 1; U.S. Geological Survey, 2013a and 2013b).

The DuPage River is formed by the East Branch DuPage River joining the West Branch of the DuPage River approximately 1.6 miles upstream of Plainfield-Naperville Road, and the stream flows generally southwestward before entering the study area (fig. 1). The basin terrain is generally flat. The study reach is approximately $15.5 \mathrm{mi}$ long, has an average top-of-bank channel width of about $180 \mathrm{ft}$ and an average channel slope of $4.4 \mathrm{ft} / \mathrm{mi}$ (U.S. Geological Survey, 2013c). Will County is still under development, as evidenced by a population increase of 35 percent (from 502,266 to 677,560) between 2000 and 2010 (U.S. Census Bureau, 2013). The land use along the study reach is a mix of commercial, residential, agricultural, and forest preserve land. The main channel within the modeled reach has fifteen major road crossings.

\section{Previous Studies}

The current FIS for Will County, Ill., and incorporated areas (Federal Emergency Management Agency, 2003), was published in 2003. The FIS includes information on the 1.0and 0.2-percent annual exceedance probability water-surface profiles and associated flood-plain maps for the DuPage River. In addition to the information in the 2003 FIS, two Letter of Map Revision (LOMR) studies were incorporated. These LOMR studies were obtained from the FEMA map library (John Adams, FEMA Engineering Library, written commun., 2012). The first LOMR study (case 02-05-3236P) is from 2002 and covers the area from 5,800 ft upstream of Black Road to 1,950 ft upstream of Black Road. The second LOMR study (case 01-05-3978P) is also from 2002 and covers the area from $100 \mathrm{ft}$ downstream of Naperville Road to approximately 1,700 ft downstream of Naperville Road. Estimates of the peak discharges for the 10-, 2-, 1-, and 0.2-percent annual exceedance probability flood along the DuPage River, as listed in table 2 for the study reach, are described by FEMA (2003).

Table 1. U.S. Geological Survey streamgage information for study area, DuPage River, Illinois.

[mi², square miles; ft, feet; NAVD 88, North American Vertical Datum of 1988]

\begin{tabular}{|c|c|c|c|c|c|c|}
\hline Station name & $\begin{array}{l}\text { Station } \\
\text { number }\end{array}$ & $\begin{array}{c}\text { Drainage } \\
\text { area } \\
\left(\mathrm{mi}^{2}\right)\end{array}$ & $\begin{array}{l}\text { Latitude } \\
\text { (degrees, } \\
\text { minutes, } \\
\text { seconds) }\end{array}$ & $\begin{array}{l}\text { Longitude } \\
\text { (degrees, } \\
\text { minutes, } \\
\text { seconds) }\end{array}$ & Period of record & $\begin{array}{c}\text { Maximum recorded } \\
\text { elevation at gage } \\
\text { (ft above NAVD 88) } \\
\text { and date }\end{array}$ \\
\hline
\end{tabular}

Table 2. 10-, 2-, 1-, and 0.2-percent annual exceedance probability peak discharge estimates and drainage areas for selected locations on the DuPage River, Illinois (modified from Federal Emergency Management Agency, 2003).

$\left[\mathrm{mi}^{2}\right.$, square miles; $\mathrm{ft}^{3} / \mathrm{s}$, cubic feet per second]

\begin{tabular}{|c|c|c|c|c|c|}
\hline \multirow[b]{2}{*}{ Location on DuPage River } & \multirow[b]{2}{*}{$\begin{array}{l}\text { Drainage area } \\
\qquad\left(\mathrm{mi}^{2}\right)\end{array}$} & \multicolumn{4}{|c|}{ Annual exceedance probability peak-discharge estimate } \\
\hline & & $\begin{array}{c}\text { 10-percent } \\
\text { discharge } \\
\text { estimate } \\
\left(\mathrm{ft}^{3} / \mathrm{s}\right)\end{array}$ & $\begin{array}{c}\text { 2-percent } \\
\text { discharge } \\
\text { estimate } \\
\left(\mathrm{ft}^{3} / \mathrm{s}\right)\end{array}$ & $\begin{array}{l}\text { 1-percent } \\
\text { discharge } \\
\text { estimate } \\
\left(\mathrm{ft}^{3} / \mathrm{s}\right)\end{array}$ & $\begin{array}{c}\text { 0.2-percent } \\
\text { discharge } \\
\text { estimate } \\
\left(\mathrm{ft}^{3} / \mathrm{s}\right)\end{array}$ \\
\hline $\begin{array}{l}\text { At Shorewood streamgage } \\
\quad(05540500)\end{array}$ & 324 & 8,470 & 11,950 & 13,690 & 17,300 \\
\hline $\begin{array}{l}\text { Approximately } 415 \text { feet } \\
\text { upstream of Renwick Road }\end{array}$ & 258 & 7,054 & 10,100 & 11,527 & 14,900 \\
\hline At Lockport Street & 252 & 6,950 & 10,000 & 11,372 & 14,800 \\
\hline $\begin{array}{l}\text { At State Route } 59 \\
\text { (Division Street) }\end{array}$ & 251 & 6,890 & 9,950 & 11,280 & 14,700 \\
\hline
\end{tabular}




\section{Constructing Water-Surface Profiles}

The water-surface profiles used to produce the nine flood-inundation maps for this study were computed by using HEC-2, version 4.6 (U.S. Army Corps of Engineers, Hydrologic Engineering Center 1991). HEC-2 is a one-dimensional step-backwater model for simulation of water-surface profiles with steady-state computation.

\section{Hydrologic and Steady-Flow Data}

Hydrologic data in the study area were from two streamgages (fig. 1; table 1): DuPage River at Shorewood, Ill. (05540500) and DuPage River near Plainfield, Ill. (05540290). The Shorewood gage was installed in April 1941 and has been used to measure gage heights and discharge continuously since installation. The records were published as "DuPage River at Troy" from 1940 through 1965. The Plainfield site was originally established as a crest-stage partial record station on October 1, 1961, and was discontinued on September 30, 1970. Crest-stage gages record information on peak gage heights. The site was then reestablished in 1978 as part of the Illinois Environmental Protection Agency (IEPA) Ambient Water-Quality Network with a wire-weight gage, and water-quality samples were taken at this location until 1988. As an IEPA wire-weight gage station, it would have typically been used to measure the gage height at the time of a waterquality sample and is unlikely to have been used for peak gage heights. The current record begins when the station was reestablished in December 2010.

Discrete discharge measurements have been made at these two sites since their respective installations. These discharge measurements are the basis for rating (stage-discharge) curves at the two streamgages from which streamflow records are computed. The current rating curve for the Plainfield streamgage was developed in 2013. All water-surface elevations are referenced to North American Vertical Datum of 1988 (NAVD 88); however, the datum for the Shorewood streamgage is listed as NGVD29 on the USGS National Water Information System: Web Interface (U.S. Geological Survey, 2013a). At the Shorewood streamgage, the NGVD29 elevation can be converted to a NAVD88 elevation by subtracting $0.3 \mathrm{ft}$ (National Geodetic Survey, 2013).

Steady-flow data consisted of flow regime, boundary conditions (normal depth downstream boundary condition), and peak discharge information. The steady-flow data for the study reach were obtained from field measurements of streamflow at the DuPage River streamgages at Shorewood and Plainfield, Ill. The stage-discharge relation (rating curve) was used to determine the flows at the Shorewood gage. The streamflow records at the Shorewood and Plainfield streamgages were used to derive a relation between peak flows at the two gages, and the Drainage-Area Ratio method (Hirsch, 1979) was used to estimate flows away from the Shorewood streamgage. This approach was used to account for the variability in individual storm events. The Drainage-Area Ratio method states that the ratio of two drainage areas $\left(\mathrm{DA}_{1} / \mathrm{DA}_{2}\right)$ raised to an exponent is equal to the ratio of the corresponding flows $\left(\mathrm{Q}_{1} / \mathrm{Q}_{2}\right)$. The ratio between the Plainfield and Shorewood streamgage drainage areas is 0.68 . After data from storm events that have occurred since the installation of the Plainfield streamgage in December 2010 were examined, the relation between the Shorewood and Plainfield streamgages was characterized by a peak flow ratio of approximately 0.71 . Using the drainage area ratio and flow ratio from the streamgages, the exponent was determined to be 0.88 . Therefore the Drainage-Area Ratio with an exponent of 0.88 was used to estimate the flows at the Plainfield gage, and upstream and downstream of the confluence with Lily Cache Creek with drainage areas of 220, 267.6, and $313.6 \mathrm{mi}^{2}$, respectively. The USGS Streamstats program (U.S. Geological Survey, 2013c) was used to calculate drainage areas for the discharge estimates.

\section{Topographic/Bathymetric Data}

The study model was an updated version of the effective FIS HEC-2 hydraulic model (FEMA, 2003). The USGS did not do any surveying in the field to change channel cross sections in the model. A Digital Elevation Model (DEM) with a grid size of $5 \mathrm{ft}$ was used to represent the ground surface. The DEM was created from spot elevations and contour lines derived from a processed Light Detection And Ranging (LiDAR) dataset collected in 2007 with accuracy sufficient to produce 2 -ft contours. The elevation and contour data were obtained from the Will County GIS Department (Nate Rock, Will County GIS Department, written commun., 2012).

The study reach includes various structures (bridges, culverts, roadway embankments, levees, and dams) that have the potential to affect water-surface elevations during floods. To properly account for these features in the model, the structures in the study reach were checked for needed updates. Structural plans for bridges were provided by Will County (Derek O'Sullivan, Will County Land Use Department, written commun., 2012). As part of this study, the USGS made updates to the HEC-2 model bridge geometry based on plans of Naperville-Plainfield Road, $111^{\text {th }}$ Street (Hassert Boulevard), $119^{\text {th }}$ Street (Rodeo Drive), $135^{\text {th }}$ Street (Pilchers Road), Division Street (State Route 59), Lockport Street, new bridge on Renwick Road, a second crossing of State Route 59, Caton Farm Road, Black Road, Jefferson Street (U.S. Route 52), and Cottage Street (State Route 59).

\section{Energy Loss Factors}

Manning's roughness coefficients (" $n$ " values) are used in hydraulic modeling for energy (friction) loss calculations. The Manning's $n$ values used ranged from 0.02 to 0.094 , and the majority of values ranged from 0.03 to 0.05 for the main channel and from 0.05 to 0.14 for the overbank areas modeled in this analysis. The main channel bed is mostly sand 
and gravel near the Shorewood streamgage and mostly sand, gravel, and silt near the Plainfield streamgage; the overbank areas are vegetated, with some areas having shrub and tree cover.

In addition to Manning's roughness coefficients, contraction and expansion coefficients of 0.3 and 0.5 , respectively, were added to the cross sections upstream and downstream of bridges.

\section{Model Verification}

Water-surface elevations calculated by the model were compared to the rating curve for the Plainfield streamgage. The Shorewood streamgage rating curve was used to determine the flows input to the model, so the Plainfield streamgage rating curve was used to verify the model performance. The difference between the model-simulated water-surface elevation and the water-surface elevation estimated from the rating curve for the nine simulated discharges (table 3 ) ranged from 0.71 to $-0.50 \mathrm{ft}$ with an average error of $-0.06 \mathrm{ft}$.

\section{Development of Water-Surface Profiles}

Water-surface profiles were developed for a total of nine gage heights at $1-\mathrm{ft}$ intervals between $6 \mathrm{ft}$ and $14 \mathrm{ft}$ as referenced to the DuPage River at Shorewood streamgage (05540500). Discharges corresponding to the various gage heights were obtained from the stage-discharge relation interpolated for the DuPage River at Shorewood streamgage. Flows corresponding to each of the gage heights to be mapped were entered into the hydraulic model at the downstream end. Two other sets of discharges were derived using the drainage area relation as described in the "Hydrologic and Steady Flow" section above. Discharges for all profiles mapped in this study reach on the DuPage River are listed in table 3.

\section{Inundation Mapping}

Flood-inundation maps were developed for the nine water-surface profiles generated for the gage heights observed at the DuPage River at Shorewood gage. Before mapping, the water-surface elevations output from the HEC-2 model were referenced to the NAVD88 vertical datum instead of the NGVD29 vertical datum by subtracting $0.3 \mathrm{ft}$. The maps were created in the ArcMap GIS (Ormsby and others, 2010) by combining the water-surface profiles and DEM data. Estimated flood-inundation boundaries for each simulated profile were created by using a DEM with a 5-ft cell size, modeled cross sections, and water-surface elevations for specific predefined stages for the cross sections derived from the HEC-2 hydraulic model. Water-surface elevation values were joined to the corresponding cross section, and a waterlevel surface for each predefined gage height was generated by using an Arc Macro Language (AML; ESRI, 1999) script. The inundation surface and the depth grids were then created by subtracting the ground-surface DEM elevations from the water-level-surface elevations. Cells with a value greater than 0.1 were retained, and the result was two grids - a flatsurface grid representing the extent of inundation and a depth grid retaining the differences between the ground-surface and water-surface elevations. The inundation maps show depth shading for estimated flooded areas overlaid on high-resolution, georeferenced aerial photographs of the study area for each of the water-surface profiles that were generated by the hydraulic model for approximately every $1-\mathrm{ft}$ change in gage height ranging from 6.0 to $14 \mathrm{ft}$. For mapping purposes, the depth grids were displayed by using a $1-\mathrm{ft}$ interval up to $2 \mathrm{ft}$, grouping depths from $2.1 \mathrm{ft}$ to $5 \mathrm{ft}$ and then one shade of color for values greater than $5 \mathrm{ft}$.

Many bridges span the DuPage River in the study reach (fig. 1). The LiDAR data used for mapping deletes the bridge decks, and the deleted area is assigned the elevation of the

Table 3. Gage heights (elevations) at USGS streamgage 05540500, DuPage River at Shorewood, Illinois, with corresponding discharge estimates at selected locations along the DuPage River, Illinois, for simulated water-surface profiles.

[NAVD 88, North American Vertical Datum of 1988; $\mathrm{ft}^{3} / \mathrm{s}$, cubic feet per second. Sheet numbers correspond to separate flood-inundation maps available online at http://pubs.usgs.gov/sim/3275/]

\begin{tabular}{lccccccccc}
\hline & \multicolumn{7}{c}{ Gage height, in feet above gage datum at the DuPage River } \\
(elevation, in feet, NAVD 88)
\end{tabular}


stream instead of the elevation of the bridge crossing the stream. Because of this feature of the LiDAR data, it was necessary to manually process the bridge deck elevations. A rectangular area representing each bridge deck was digitized and assigned the minimum elevation of the bridge deck from bridge data in the HEC-2 hydraulic model. These rectangular areas were then merged into the land-elevation DEM, so when the inundated area was subtracted from the land-surface elevation, the bridge decks remained above the inundated surface when the road was not inundated. In the published maps, however, the bridge decks are shown as inundated when the roads approaching the bridge decks are inundated in order to discourage people from crossing the bridge.
A.

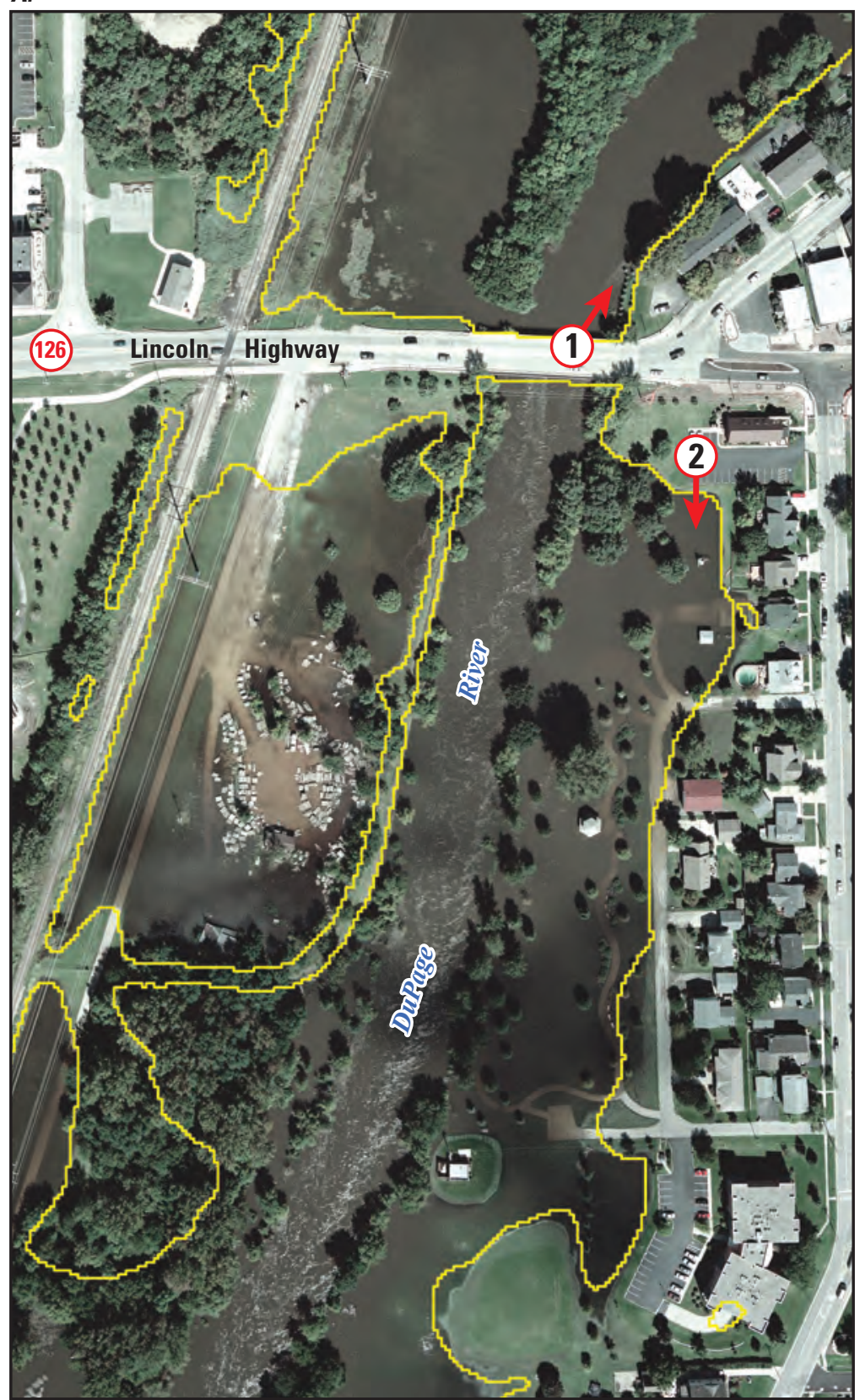

B.
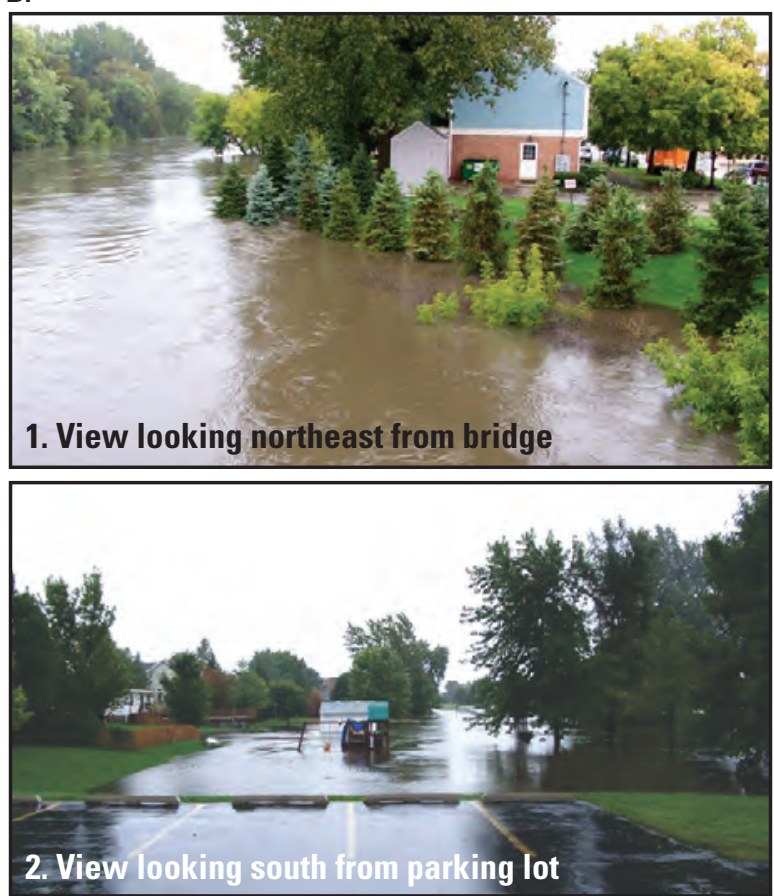

Photos from dupageriverflooding.com

\section{EXPLANATION}

Extent of flood inundation corresponding to a gage height (elevation) of 10.0 (574.3) feet at U.S. Geological Survey streamgage number 05540290, DuPage River at Shorewood

Location and direction of photo showing flooding on the DuPage River on September 14, 2008

Illinois State route marker

Photo provided by Will County, Illinois Land Use Department.

Figure 2. A, Aerial photograph taken after the flood peak in September 2008 overlaid with simulated flood inundation corresponding to a gage height (elevation) of 10.0 (574.3) feet at U.S. Geological Survey streamgage number 05540500, DuPage River at Shorewood, Illinois, and $B$, photos of flooding along the DuPage River on September 14, 2008, at locations 1 and 2 in photo A. The peak gage height for this flood was measured at 9.94 feet at the Shorewood streamgage on September 15, 2008. (Refer to figure 1 for the location where photo A was taken.) 


\section{Inundation Verification}

Aerial photographs taken during the September 2008 flooding along the DuPage River in Will County by The Sidwell Company were provided by Will County (Derek O'Sullivan, Will County Land Use Department, written commun., 2013). The peak gage height during this event was $9.94 \mathrm{ft}$ on September 15, 2008, as measured at the Shorewood streamgage (U.S. Geological Survey, 2013a). The extent of flooding shown in the aerial photography is comparable with the boundaries of the inundation surface generated for the gage height of $10 \mathrm{ft}$ at the Shorewood streamgage.

\section{DuPage River, Illinois, Flood-Inundation Maps on the Internet}

The flood-inundation maps and current study documentation are available online at the USGS Publications Warehouse (http://pubs.usgs.gov/sim/3275). Also, a USGS Flood Inundation Mapping Science World Wide Web portal has been established at http://water.usgs.gov/osw/flood_inundation/ to provide a portal for USGS estimated flood-inundation information to the public. That Web portal has a link (http://wim.usgs.gov/ FIMI/FloodInundationMapper.html) to interactive online map libraries that can be downloaded in several commonly used electronic file formats. The maps from this study showing the extent of inundated areas can be downloaded in three electronic file formats from that portal; (1) GIS shapefile format, (2) Keyhole Markup Language zipped file format (KMZ), and (3) Portable Document Format (PDF). Users can print out formatted maps or create customized maps using available GIS data layers. Each stream reach displayed on the Web site contains links to NWISWeb graphs of the current gage height at USGS streamgage DuPage River at Shorewood, to which the inundation maps are referenced. A link also is provided to the NWS AHPS site (http://water.weather.gov/ahps/) so that the user can obtain applicable information on forecasted peak stage. The estimated flood-inundation maps are displayed in sufficient detail to note the extent of flooding with respect to individual structures so that preparations for flooding and decisions for emergency response can be performed efficiently. Roadways and bridges were closely reviewed and are shown as shaded (inundated and likely impassable) or not shaded (dry and passable) to facilitate emergency planning and use. However, buildings which are shaded do not reflect inundation but denote that bare earth surfaces in the vicinity of the buildings are inundated. When the water depth in the vicinity of the building of interest exceeds that building's height, the structure can be considered fully submerged.

\section{Disclaimer for Flood-Inundation Maps}

Inundated areas shown should not be used for navigation, regulatory, permitting, or other legal purposes. The USGS provides these maps "as-is" for a quick reference, emergency planning tool but assumes no legal liability or responsibility resulting from the use of this information.

\section{Uncertainty and Limitation Associated With Inundation Maps}

Although the flood-inundation maps represent the boundaries of inundated areas with a distinct line, some uncertainty is associated with these maps. The flood boundaries shown were estimated on the basis of gage heights (water-surface elevations) and streamflows (discharges) at a selected USGS streamgage. Water-surface elevations along the stream reaches were estimated by steady-state hydraulic modeling, assuming unobstructed flow, and using streamflows and hydrologic conditions anticipated at the USGS streamgage. The hydraulic model reflects the land-cover characteristics and any bridge, dam, levee, or other hydraulic structures existing in November 2012. Unique meteorological factors (timing and distribution of precipitation) may cause actual streamflows along the modeled reach to vary from those assumed during a flood, which may lead to deviations in the water-surface elevations and inundation boundaries shown. Additional areas may be flooded due to unanticipated conditions such as changes in the streambed elevation or roughness, backwater into major tributaries along a main stem river, or backwater from localized debris or ice jams. The accuracy of the floodwater extent portrayed on these maps will vary with the accuracy of the digital elevation model used to simulate the land surface. Additional uncertainties and limitations pertinent to this study may be described elsewhere in this report.

If this series of flood-inundation maps will be used in conjunction with NWS river forecasts, the user should be aware of additional uncertainties that may be inherent or factored into NWS forecast procedures. The NWS uses forecast models to estimate the quantity and timing of water flowing through selected stream reaches in the United States. These forecast models (1) estimate the amount of runoff generated by precipitation and snowmelt, (2) simulate the movement of floodwater as it proceeds downstream, and (3) predict the flow and stage (water-surface elevation) for the stream at a given location (AHPS forecast point) throughout the forecast period (every 6 hours and 3 to 5 days out in many locations). For more information on AHPS forecasts, please see http://water. weather.gov/ahps/pcpn_and_river_forecasting.pdf. 


\section{Summary}

A series of estimated flood-inundation maps for the DuPage River between Plainfield and Shorewood, Illinois, were developed in cooperation with the Will County Stormwater Management Planning Committee. These maps (available at $h$ ttp://water.usgs.gov/osw/flood_inundation/), in conjunction with the real-time gage-height data from the USGS streamgage at the DuPage River at Shorewood, Ill. (station no. 05540500), and National Weather Service flood-stage forecasts, can help to guide the general public in taking individual safety precautions and can provide city officials with a tool to efficiently manage emergency flood operations and flood mitigation efforts.

The maps were developed by using the HEC-2 and ArcMap programs to compute water-surface profiles and to delineate estimated flood-inundation areas for selected gage heights. The maps show depth shading for estimated flood-inundation areas overlaid on high-resolution, georeferenced aerial photographs of the study area for gage heights between $6 \mathrm{ft}$ and $14 \mathrm{ft}$ at the DuPage River at Shorewood, Ill. streamgage.

\section{References Cited}

ESRI, 1999, ARC Macro Language, self-study workbookDeveloping ARC/INFO menus and macros with AML: Redlands, California, ESRI Press, 828 p.

Federal Emergency Management Agency, 2003, Flood insurance study, Will County, Illinois, and incorporated areas: Flood Insurance Study Number 17197CV001A [variously paginated].

Federal Emergency Management Agency, 2008, Illinois severe storms and flooding - FEMA-1800-DR, Illinois: accessed January 28, 2013, at http://www.fema.gov/pdf/news/ pda/1800.pdf.

Hirsch, R.M., 1979, An evaluation of some record reconstruction techniques: Water Resources Research, v. 18, no. 4, p. 1081-1088.

Illinois State Geological Survey, 2013, Physiographic divisions of Illinois: accessed February 12, 2013, at $h t t p: / / w w w$. isgs.illinois.edu/maps-data-pub/publications/physio.shtml.

National Geodetic Survey, 2013, VERTCON-North American Vertical Datum Conversion: accessed July 31, 2013, at http://www.ngs.noaa.gov/TOOLS/Vertcon/vertcon.html.

Ormsby, Tim; Napoleon, E.J.; Burke, Robert; Groessl, Carolyn; and Bowden, Laura, 2010, Getting to know ArcGIS Desktop: Redlands, California, ESRI Press, 604 p.
U.S. Census Bureau, 2013, Will County QuickFacts: accessed January 28, 2013, at http://quickfacts.census.gov/qfd/ states/17/17197.html.

U.S. Army Corps of Engineers, Hydrologic Engineering Center, 1991, HEC-2 Water surface profiles-User's manual: $334 \mathrm{p}$.

U.S. Geological Survey, 2013a, National Water Information System - Web Interface, USGS 05540500 DuPage River at Shorewood, IL: accessed January 28, 2013, at http://waterdata.usgs.gov/nwis/nwismap/?site no $=05540500 \&$ agency_cd $=U S G S$.

U.S. Geological Survey, 2013b, National Water Information System-Web Interface, USGS 05540290 DuPage River near Plainfield, IL: accessed January 28, 2013, at http://waterdata.usgs.gov/nwis/nwismap/?site_ $n o=05540290 \&$ agency $c d=U S G S$.

U.S. Geological Survey, 2013c, Illinois Streamstats: accessed January 31, 2013, at http://streamstats.usgs.gov/ illinois.html.

\section{Glossary}

Annual exceedance probability The annual exceedance probability is the probability, or chance, of a flood of a given streamflow magnitude being equaled or exceeded in any given year. As an example, a 1-percent annual exceedance probability flood has a 1-percent chance of being equaled or exceeded in any single year. A 1-percent annual exceedance probability flood is also referred to as a 100-year flood.

DEM A Digital Elevation Model (DEM) is a digital file consisting of terrain elevations for ground positions at regularly spaced horizontal intervals.

Depth grid A digital file consisting of the mathematical difference between the water-elevation surface and ground-elevation surface for ground positions at regularly spaced horizontal intervals.

Gage height Gage height is the term used by the USGS National Water Information System display to describe the height of water above the datum at a streamgage. It is synonymous with stage.

Inundation surface The mathematical difference between the waterand ground-elevation surface results in the inundation surface, which represents the area covered by water.

Rating curve A rating curve is the relation between stage and discharge at a cross section in a river.

Stage Stage is the term used by the National Weather Service to describe the height of water above the datum at a streamgage. It is synonymous with gage height.

Water-surface elevation Water-surface elevation at a streamgage is determined by adding the gage height of the water to the datum for the streamgage.

Water-surface profile A water-surface profile shows how the elevation of a river changes along its centerline. 

